\title{
ASSESSMENT OF THE ACTIVITY OF ATOVAQUONE-LOADED NANOCAPSULES IN THE TREATMENT OF ACUTE AND CHRONIC MURINE TOXOPLASMOSIS
}

\author{
SORDET F. ${ }^{*}$, AUMJAUD Y.**, FESSI H.** \& DEROUIN F.*
}

\section{Summary :}

The aim of this work was to develop a new pharmaceutical form of atovaquone and to study its activity against Toxoplasma gondii in vitro and in vivo. Nanocapsules were chosen as the oral dosage form of administration. An analytical method was developed to determine the drug content in nanocapsules. The stability of these nanocapsules were assessed by following drug content, size, $\mathrm{pH}$ and osmolarity for a period of six months. The in vitro activity of atovaquone-loaded nanocapsules against tachyzoites of T.gondii (RH stain) was comparable to its suspension form. In vivo studies were carried out in murine models of acute and chronic toxoplasmosis. Mice acutely infected with the virulent $\mathrm{RH}$ strain were orally treated with a dose regimen of $15 \mathrm{mg} / \mathrm{kg} /$ day for 10 days, starting from day 1 post-infection. $75 \%$ of the mice receiving atovaquone-loaded nanocapsules survived 30 days post-infection, compared to none of untreated controls and none of mice treated with the suspension with the same dose regimen. In mice chronically infected by the COUL or the ME49 strain (Type II strains), then treated for six weeks, treatment with atovaquone $115 \mathrm{mg} / \mathrm{kg} / \mathrm{d}$, nanoparticles or suspension) resulted in a decrease of brain parasitic burden, which was significantly more pronounced in ME49-infected mice and in those treated with drug-loaded nanocapsules. These results show that the sensibility of T.gondii to atovaquone is different according to the strains and that the activity of atovaquone in the treatment of toxoplasmosis is enhanced when administered in nanoparticular form.

KEY WORDS : atovaquone, Toxoplasma gondii, cerebral toxoplasmosis, nanocapsules, murine models
Résumé : Évaluation de L'ACTIVITÉ DE NANOCAPSULES D'ATOVAQUONE DANS LE TRAITEMENT DE LA TOXOPLASMOSE MURINE AIGÜE ET CHRONIQUE

L'objectif de ce travail était de développer une nouvelle forme galénique de l'atovaquone (nanocapsules per os) et d'en étudier l'activité sur Toxoplasma gondii in vitro et in vivo. Une méthode analytique a été mise au point afin de déterminer la quantité d'atovaquone intégrée dans les nanocapsules. La bonne stabilité des nanocapsules a été contrôlée par mesure de leur taille, leur $\mathrm{pH}$, leur osmolarité et leur concentration en atovaquone, sur une période de six mois. L'activité in vitro des nanocapsules d'atovaquone sur les tachyzoïtes de T.gondii (souche RH) s'est révélée comparable à celle observée avec la forme suspension. Les études in vivo ont été menées sur des modèles murins de toxoplasmose aigüe et chronique. Des souris infectées par souche virulente RH ont été traitées pendant dix jours par une dose d'atovaquone (suspension ou nanoparticules) de $15 \mathrm{mg} / \mathrm{kg} / \mathrm{jour}$, de $\mathrm{Jl}$ à $\mathrm{J} 10$ post-infection. $75 \%$ des souris recevant la forme nanoparticule d'atovaquone étaient vivantes 30 jours après l'infection alors qu'aucune n'avait survécu parmi les souris non traitées ou traitées par la suspension d'atovaquone. Chez des souris présentant une toxoplasmose chronique (souche COUL et ME49 de type II), un traitement de six semaines par atovaquone $115 \mathrm{mg} / \mathrm{kg} / \mathrm{i}$, suspension ou nanocapsules, a permis une baisse importante de la charge parasitaire cérébrale. Cette baisse fut significativement plus marquée chez les souris infectées par la souche ME49 et chez celles traitées par la forme nanocapsulaire. Ces résultats montrent donc que la sensibilité à l'atovaquone est variable selon les souches et que la forme nanocapsulaire est d'une efficacité supérieure à la forme suspension dans le traitement de la toxoplasmose.

MOTS CLÉS : atovaquone, Toxoplasma gondii, toxoplasmose cérébrale, nanoparticules, modèle murin.

plus pyrimethamine proved efficient in preventing relapses of previously acquired Toxoplasma infection, and the large application of prophylactic recommandations have resulted in marked decrease of the incidence of toxoplasmic encephalitis (Richards et al., 1995; USPHS/IDSA, 1995; Leport et al., 1996; Girard et al., 1996). However, the drugs that are presently recommended for prophylaxis of toxoplasmosis (and pneumocystosis) are not effective against brain cysts, and do not eradicate the parasite from the organism. This limit justifies their life-long administration to patients at risk (i. e. those who are seropositive for $T$. gondii), but also underlies the need for new com-

pounds that would eradicate cysts in chronically
* Laboratoire de Parasitologie-Mycologie, Hôpital Saint-Louis, 1, avenue Claude-Vellefaux, 75475 Paris Cedex 10, France.

** Laboratoire de Pharmacie Galénique, ISPB - Faculté de Pharmacie, 8, avenue Rockefeller, 69373 Lyon Cedex 08, France.

Correspondence: Francis Derouin.

Tel: 33142499503 - Fax: 33142494803 . 
infected patients and more particularly drugs that could be given orally.

Atovaquone might be such a candidate drug, as several studies have shown its activity against Toxoplasma cysts, both in vitro and in vivo (Huskinson et al., 1991; Araujo et al., 1992). However, both clinical and experimental data indicate that two main factors could limit its use for primary prophylaxis. First, the bioavailability of atovaquone is low ( $47 \%$ in patients with AIDS, when suspension is taken with fatty food) with an important inter-individual variability (Hugues et al., 1991). Second, experimental studies have demonstrated the variable sensitivity of different strains of Toxoplasma gondii to this drug (Tomavo et al., 1995; Araujo et al., 1991).

Thus, improvement of the bioavailability of atovaquone, through the use of drug-loaded carriers, could represent a valuable solution in increasing intra-cellular and tissue drug concentrations (Kreuter, 1994; Fusai et al., 1997) and thus achieving inhibitory levels effective on less sensitive strains. Because of the physicochemical characteristics of the drug, i. e. poor water solubility, nanocapsules have been chosen as a colloidal drug carrier. Nanocapsules have a higher drug loading capacity than nanospheres and have the advantages over other drug carriers such as liposomes of being physically and chemically more stable during storage (Puisieux et al., 1994). Furthermore, they are stable in the presence of biliary salts (Devissaguet et al., 1992), which is a major requirement for oral administration. The main objective of this work was to prepare stable drug-loaded nanocapsules and to compare the efficacy of these colloidal drug carriers to the water-based suspension in the treatment of acute and chronic toxoplasmosis.

\section{MATERIALS AND METHODS}

\section{DRUG PREPARATIONS}

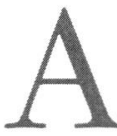

tovaquone was obtained from Glaxo-Wellcome (France) under two forms: a powdered form which was used to prepare nanocapsules and for in vitro studies, and a liquid suspension form. The polymer Poly (D, L-lactide) (PLA) of molecular weight 88,000 was purchased from Boeringher Ingelheim (Germany); oleic acid, benzyl benzoate and caprylic/capric acid or Miglyol $812^{\circledR}$ from Cooper (Melun, France); Labrafac ${ }^{\circledR}$ from Gattefosse (Lyon, France). The surfactant used was Synperonic PE/F $68^{\circledR}$ from ICI (Clamart, France) and a phospholipid mixture, Epikuron $170^{\circledR}$ was purchased from Lucas Mayer (Hamburg, Gremany). All other solvants were of appropriate grade and were obtained from Prolabo (Paris, France) and Aguettant (Lyon, France).
Prior to the preparation of nanocapsules, solubility studies were conducted at $4{ }^{\circ} \mathrm{C}$ and room temperature to determine the maximum solubility of atovaquone in each of the following oils: oleic acid, benzyl benzoate, Miglyol $812^{\circledR}$, or Labrafac ${ }^{\circledR}$. The solubility study has also served to determine storage conditions of drug-loaded nanocapsules.

\section{Preparation of nanocapsules}

Free and atovaquone-loaded nanocapsules of PLA were prepared using a modification of the process described by Fessi et al. (1989). 125 mg of PLA was dissolved into an organic phase consisting of $25 \mathrm{ml}$ acetone, $100 \mathrm{mg}$ Epikuron $170^{\circledR}$ and $0.5 \mathrm{ml}$ of a chosen oil (benzyl benzoate, Miglyol $812^{\circledR}$, Labrafac ${ }^{\circledR}$ or oleic acid) either free or containing a required quantity of atovaquone. The combined organic phase was injected into $50 \mathrm{ml}$ of water containing $100 \mathrm{mg}$ of Synperonic $\mathrm{PE} / \mathrm{F} 68^{\circledR}$ under moderate magnetic stirring. The acetone and some water were evaporated under reduced pressure. The resulting nanocapsule preparation was filtered on sintirred glass with a porosity range of 915 micrometers and the final volume adjusted to $10 \mathrm{ml}$. Sufficient quantities of both free and atovaquoneloaded nanocapsules were prepared for stability and in vivo studies.

Nanocapsules were kept in sealed glass bottles at room temperature and away from light throughout the study.

\section{Dosage of atovaquone}

Atovaquone was assayed by high-performance liquid chromatography using a modified method of DeAngelis et al. (1994). The system consisted of a LiChospher 100 RP, C18 reverse phase column, fitted with a precolumn. The autosampler, pump and UV detection device were integrated in the Hewlett Packard $1050^{\circledR}$ system. The mobile phase consisted of acetonitrile/ water/glacial acetic acid $(85: 15: 5 \mathrm{v} / \mathrm{v})$. The volume of sample injected was $10 \mu \mathrm{l}$ and was eluted at a constant flow rate of $3.0 \mathrm{ml} / \mathrm{min}$. Atovaquone was detected by absorption at $254 \mathrm{~nm}$. An average retention time of 1.7-1.8 minutes was obtained in the linear response range of 12.4$198.0 \mu \mathrm{g} / \mathrm{ml}$ with a correleation coefficient of 0.999 .

Drug content of nanocapsules and stability studies

Total drug concentration in nanocapsules was determined by dissolving the polymer membrane in mobile phase and dosing for atovaquone. Encapsulated drug was calculated from the difference between total drug and that in the aqueous phase. Aqueous phase drug content was determined in the clear filtrate following separation of nanocapsules from the aqueous medium by a combined ultrafiltration-centrifugation technique (Ultrafree MC $^{\circledR}$ 10,000 Daltons, Millipore, France). 
Nanocapsule yield and encapsulation rate were hence calculated and used in stability studies. Nanocapsules with atovaquone concentrations of $1,000 \mu \mathrm{g} / \mathrm{ml}$ were prepared.

Nanocapsule mean size was followed by Nanosizer $\mathrm{N} 4^{\circledR}$ (Coultronics, Margency, France). Osmolarity and $\mathrm{pH}$ measurements were used to follow nanocapsule stability over six months.

\section{PARASITES-STRAINS OF TOXOPLASMA GONDII}

The RH strain of T. gondii was used for in vitro studies and in vivo experiments in the model of acute toxoplasmosis. This strain was maintained in Swiss mice by 3-days interval intraperitoneal passage; for each experiment, tachyzoites were harvested from the peritoneal cavity of mice infected two days earlier then centrifuged at $1,500 \mathrm{G}$. The pellet was resuspended in sterile phosphate buffer solution $\mathrm{pH} 7.2$ (PBS) then parasites were adjusted at a concentration of $10^{4} / \mathrm{ml}$

Two different strains of $T$. gondii belonging to the type II (Howe et al., 1995) were used for inducing chronic infections in mice. This type of strain was selected as representative of the majority of strains isolated in HIV infected individuals (Howe et al., 1997), and responsible for chronic toxoplasmic infection in mice. The ME 49 strain (kindly provided by Prof. M.L. Dardé, Limoges, France) was used, since previous experiments by Huskinson et al. (1991) showed that treatment of chronically-infected mice with atovaquone could significantly reduce the cyst burden in brain and induce ultrastructural alteration of the cyst structure. The COUL strain (Beauvais et al., 1982), which has been extensively studied in our laboratory, was also selected because it produces chronic infection with mature cysts and stable brain infection (Derouin et al., 1991). These strains were maintained in mice under a chronic form by 6-months interval passages in Swiss Webster mice. For each experiment, cysts were obtained from the brain of mice infected at least six months previously.

\section{IN VITRO EXPERIMENTS}

In vitro studies were carried out using MRC5 fibroblast tissue cultures as previously described (Derouin et al., 1989). Briefly, confluent monolayers prepared in 96well tissue culture plates were inoculated with 1,500 tachyzoites of the RH strain. After four hours, serial dilutions of each drug preparation were added into the medium and cultures were incubated for an additional 72 hours. Toxoplasma growth was assessed by an enzyme-linked immunoassay performed directly on the fixed cultures. For each well, results were expressed as optical density values. Ten concentrations of atovaquone (free drug and nanocapsules), ranging between 0.001 and $1 \mu \mathrm{g} / \mathrm{ml}$, were tested; each concentration was studied in eight replicate wells and in two replicate culture plates. Regression models were used to summarize the in vitro dose-effect relationship and to determine the $50 \%$ inhibitory concentration $\left(\mathrm{IC}_{50}\right)$.

\section{IN VIVO EXPERIMENTS}

Female Swiss Webster mice weighing 18-20 grams (Iffa Credo, France) were used for optimum reproducibility and breeding facilities.

Acute infection by the RH strain were induced by intraperitoneal injection of $2.10^{4}$ freshly harvested tachyzoites.

Chronic toxoplasmosis were induced by oral infection with ten cysts obtained from the brain of mice that had been infected for at least six months. Fourty-five mice were infected with each strain; four months after infection, mice were allocated in the different treatment groups.

\section{TREATMENT PROTOCOLS}

\section{Treatment of acute toxoplasmosis}

At day 1 (D1) post infection, mice were allocated in four groups: one control group of ten infected untreated mice and three treatment groups of ten mice each: one group was treated with unloaded nanocapsules, one group was treated with $15 \mathrm{mg} / \mathrm{kg}$ /day of atovaquone-loaded nanocapsules, and one group was treated with $15 \mathrm{mg} / \mathrm{kg} /$ day of atovaquone suspension. Treatments were administered daily by tube feeding for a 10-day period. This dosage and duration of treatment was selected as it was previously found only partially effective in mice treated with the liquid suspension of atovaquone (Araujo et al., 1991; Romand et al., 1993) and thus would be appropriate to reveal a potentially higher efficiency of the treatment with atovaquoneloaded nanocapsules.

\section{Treatment of chronic toxoplasmosis}

From the results of treatment of acute toxoplasmosis, the dosage of $15 \mathrm{mg} / \mathrm{kg} /$ day was selected for treatment of chronic infection. For each strain of $T$. gondii, mice infected for four months were allocated in the following treatment groups (10 mice in each group): untreated controls, treatment with $15 \mathrm{mg} / \mathrm{kg}$ /day of atovaquone-loaded nanocapsules, and treatment with $15 \mathrm{mg} / \mathrm{kg} /$ day of atovaquone suspension. Mice were treated daily by gavage during six weeks, five days a week.

\section{ASSESSMENT OF THERAPEUTIC EFFICACY}

Survival of mice was recorded in each treatment group. In acutely infected mice, parasite burdens were deter- 
mined at D6 post infection in blood, brain and lung of two mice in each treatment group. In chronicallyinfected mice, brain cyst count and parasitic burdens were estimated at the begining and at the end of treatment. At each date, five mice were sacrificed; their brains were removed, weighed, then homogeneized in $2 \mathrm{ml}$ of PBS, using an Ultra Turrax T25 homogenizer (Staufen, Germany). The resulting homogenate was examined microscopically for cyst counts and titrated for parasitic burdens. Atovaquone concentrations have not been determined in blood or tissue homogenates. Cysts were counted on four blinded samples of $50 \mu \mathrm{l}$ of each brain homogenate (treated, untreated), and the total number of cyst was recorded and $\times 100$ to obtain an estimate of the total brain cysts count.

Parasitic titration in brain was estimated according to the culture technique described by Piketty et al. (1990). Briefly, serial fourfold dilutions of the brain suspension were prepared in basal culture medium and $40 \mu \mathrm{l}$ of each dilution was inoculated in duplicate in 96-well MRC5 fibroblast tissue culture plates. After 96 hours of incubation at $37{ }^{\circ} \mathrm{C}$ in a moist $5 \% \mathrm{CO}_{2}-95 \%$ air atmosphere, plates were fixed with cold methanol then airdried. Cultures were examined for $T$. gondii by means of an indirect immunofluorescence assay, using a polyclonal rabbit anti-antibody as first antibody and a fluorescein-labeled anti-rabbit IgG conjugate as second antibody; plates were examined under a fluorescence microscope and the presence of fluorescent parasites was recorded in each well. For each brain homogenate, the titer was defined as the last dilution at which the tissue culture contained at least one parasite focus. The parasitic burden per gram of tissue was calculated as the reciprocal titer in tissue culture/weight (milligrams) $\times 1,000$.

\section{STATISTICS}

In mice, the survival rates were estimated by the Kaplan-Meier product limit method and compared using the log-rank test. The mean value for the parasite burden from five mice ( \pm 1 standard error) was calculated for each time point. Statistical comparison of the parasitic loads were determined according to the Mann-Whitney non-parametric test; $p$ values $<0.05$ were considered as significant.

\section{RESULTS}

\section{PREPARATION OF ATOVAQUONE-LOADED NANOCAPSULES}

tability studies showed that the highest possible payload could be achieved by using benzyl ben1 zoate as the oily core, reaching a concentration of $24.2 \mathrm{mg} / \mathrm{ml}$ whereas maximum concentrations in other solvent oils were $\leq 7.5 \mathrm{mg} / \mathrm{ml}$.

With benzyl benzoate, the maximum possible concentration of atovaquone that could be loaded per $\mathrm{ml}$ of nanocapsule suspension was estimated to be $1.2 \mathrm{mg}$. Solubility studies also showed that atovaquone formed needle-shape crystals in the oily phase at $4^{\circ} \mathrm{C}$ and storage at this temperature would break the structure of the nanocapsules. From these results, atovaquone nanocapsules were prepared and stored at room temperature until use.

Two batches were prepared at $1 \mathrm{mg} / \mathrm{ml}$ (Table I). At this concentration, nanocapsule yields were respectively $84.5 \%$ and $82.9 \%$ and encapsulation rates were $100 \%$ for both batches, showing that atovaquone could be encapsulated into nanocapsules with a reasonable yield. Stability studies were performed on the second batch, which was also used for experimental studies on T. gondii. Size distribution and polydispersity showed that the nanocapsules were stable over a period of six months despite a moderate and constant decline in size, from a mean value of $206 \mathrm{~nm}$ at the date of preparation ( $t 0)$ to $170 \mathrm{~nm}$ at six months. The increase in osmolarity $(6 \mathrm{mOsm}$ at $t 0$ to $21 \mathrm{mOsm}$ at six months) and the decrease in $\mathrm{pH}$ ( $\mathrm{pH} 4.23$ at $t 0$ to $\mathrm{pH} 3.10$ at six months) that were observed are in favor of a moderate degradation of the polymer membrane, corresponding to a $10 \%$ biodegradation of PLA into lactic acid.

\section{IN VTTRO EXPERIMENTS ON TOXOPLASMA GONDII}

The in vitro activity of the suspension and the nanocapsule forms of atovaquone on Toxoplasma gondii (RH strain) was estimated in two separate experiments for concentrations ranging between 1 and $10^{-3} \mathrm{mg} / \mathrm{l}$. The results presented on figure 1 for one representative experiment showed that the inhibitory effect on Toxoplasma growth according to the concentration

\begin{tabular}{ccccccc}
\hline Batch & $\begin{array}{c}\text { Concentration } \\
(\mathrm{mg} / \mathrm{ml})\end{array}$ & $\begin{array}{c}\text { Yield } \\
(\%)\end{array}$ & $\begin{array}{c}\text { Encapsulation rate } \\
(\%)\end{array}$ & $\begin{array}{c}\text { Average size } \\
(\mathrm{nm})\end{array}$ & $\begin{array}{c}\text { Polydispersity } \\
\mathrm{pH}\end{array}$ & $\begin{array}{c}\text { Osmolarity } \\
(\mathrm{mOsm})\end{array}$ \\
\hline 1 & 1 & 84.53 & 100 & 273 & 0 & - \\
$2(t=0)$ & 1 & 82.91 & 100 & 206 & 0 & 6 \\
$2(t=6$ months $)$ & 1 & 81.82 & 100 & 170 & 2 & 4.23 \\
\hline
\end{tabular}

Table I. - Atovaquone loaded nanocapsules: yield, encapsulation rate, average size, polydispersity, osmolarity and pH of the prepared batches. 


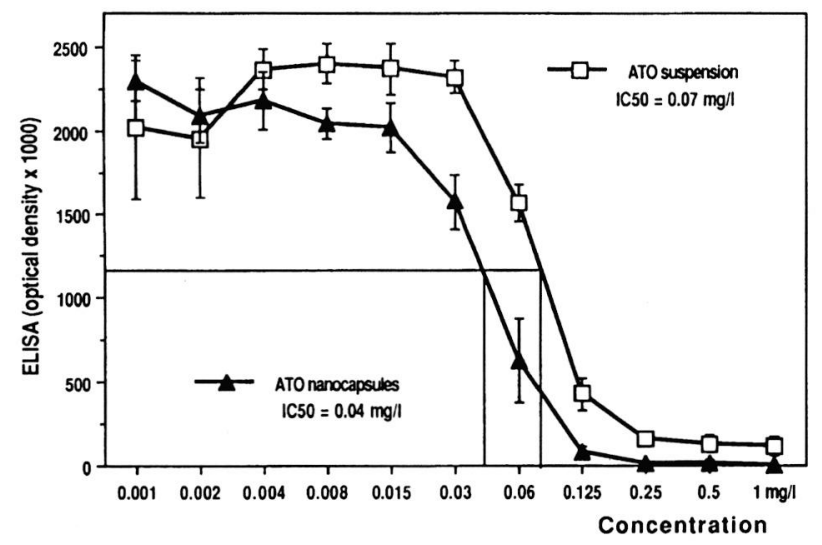

Fig. 1. - In vitro inhibitory effect of atovaquone suspension and nanocapsules on Toxoplasma gondii growth. Mean optical density values for ELISA versus concentration of atovaquone suspension ( $\vec{C}$ ) or nanocapsules $(\mathbf{\Delta})$. For each concentration the mean optical density values \pm standard error were calculated from 8 replicate culture wells. IC $50=50 \%$ inhibitory concentration.

was roughly similar for both preparations. From the regression curve analysis, the $\mathrm{IC}_{50}$ were estimated at a concentration of $0.04 \mu \mathrm{g} / \mathrm{ml}$ with the suspension and $0.07 \mu \mathrm{g} / \mathrm{ml}$ for atovaquone-loaded nanocapsules.

\section{TREATMENT OF TOXOPLASMOSIS}

\section{Acute toxoplasmosis}

In this experiment, assessment of treatment efficacy was based on the survival in each group of mice and the determination of parasitic burden in blood, brain and lungs in two mice at D6 post-infection. Untreated mice and mice treated with unloaded nanocapsules died within seven days (Fig. 2); in both groups, mice presented high parasitic burdens with a mean respective value of 4.10 and $5.01 \mathrm{log}$ parasites $/ \mathrm{ml}$ in blood, 5.75 and $5.33 \mathrm{log}$ parasites/g in the brain and 6.87 and $6.80 \mathrm{log}$ parasites/g in the lungs. When compared to the treatment with the suspension of atovaquone, a delay in time to death was noted, but $100 \%$ died by D12. At D6, parasites were not detectable in the blood, whereas mean parasitic burdens were at $3.82 \log$ para-

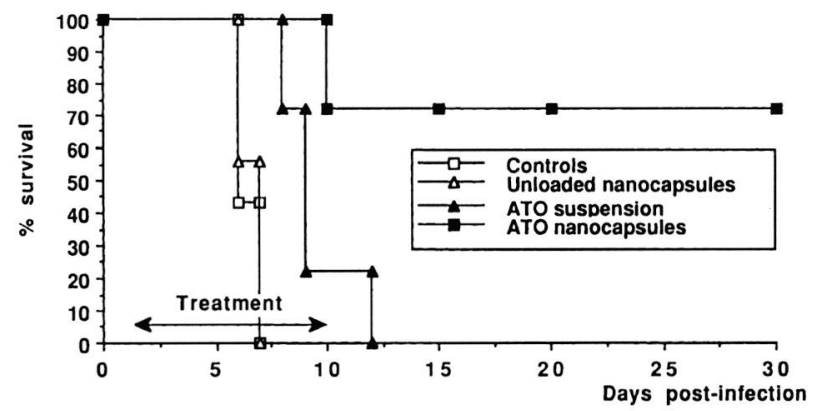

Fig. 2. - Acute toxoplasmosis. Survival rates for control mice ( $\square$ ) and mice treated with unloaded nanocapsules $(\Delta)$, atovaquoneloaded nanocapsules $(\boldsymbol{\square})$, or atovaquone suspension $(\boldsymbol{\Delta})$, from day 1 to day $10(15 \mathrm{mg} / \mathrm{kg} /$ day $)$. sites/g in the brain and $6.18 \mathrm{log}$ parasites/g in the lungs. In the group of mice treated with atovaquoneloaded nanocapsules, $75 \%$ of mice survived until D30; parasites were undetectable in the blood and in the brains at $\mathrm{D} 6$ and were at a low value in the lungs (mean $=1.90 \mathrm{log}$ parasites $/ \mathrm{g}$ ). In the surviving mice at D30, no cyst were found by microscopic examination of serial brains smears.

\section{Chronic toxoplasmosis}

Chronically infected mice were followed during 42 days after initiation of treatment. No death was recorded in untreated mice infected by the COUL strain, whereas $30 \%$ of untreated ME- 49 infected mice died during the follow-up period.

Assessment of treatment efficacy was based on the determination of brain cysts counts and parasitic burden at the end of treatment (D42). Results obtained for both strains according to the treatment administered are presented in Figure $3 a$ and $3 b$. Overall, the results

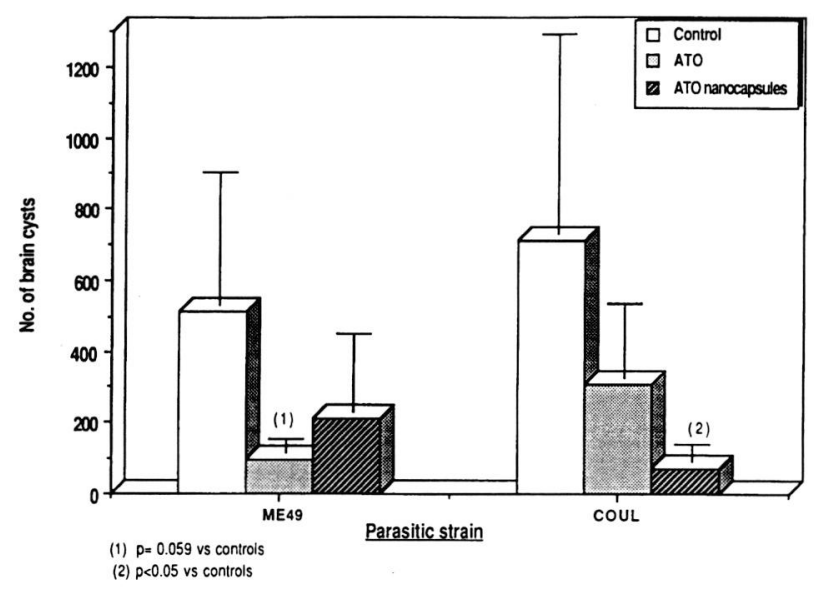

Fig. 3a. - Chronic toxoplasmosis. Brain cyst count versus treatment (control, atovaquone suspension or nanoparticles $(15 \mathrm{mg} / \mathrm{kg} /$ day) and parasitic strain (COUL or ME49).

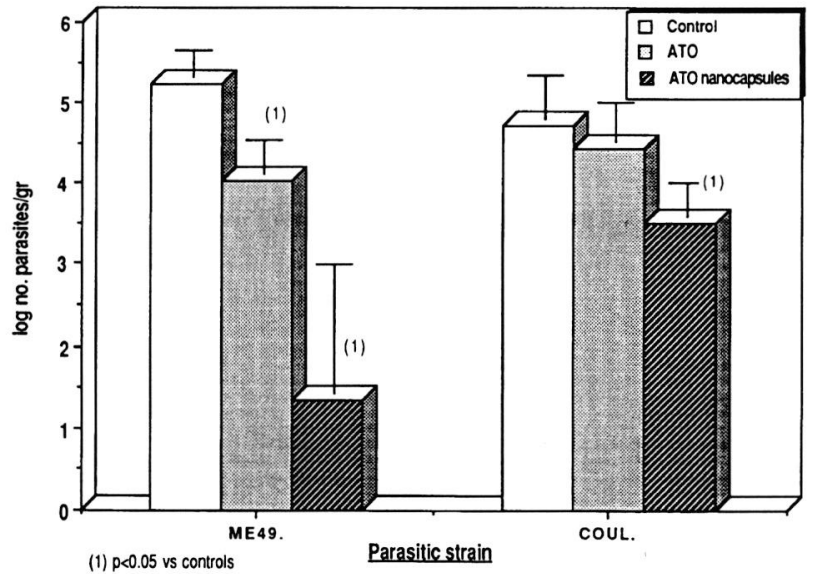

Fig. 3b. - Chronic toxoplamosis. Parasitic burdens versus treatment (control, atovaquone suspension, or nanoparticles $(15 \mathrm{mg} / \mathrm{kg} /$ day) and parasitic strain (COUL or ME49). 
showed a marked efficacy of atovaquone on brain infection, either assessed by brain cyst count or titration of parasitic burdens. However, an important heterogeneity was noted following the type of infecting strain, the drug formulation and the method that was used to quantify parasitic infection in the brain.

The quantification of brain cysts showed that all mice were infected but it revealed an important variability in cyst counts among control mice, for both strains of T. gondii. In treated mice, a marked reduction of cyst counts was noted in comparison to the controls but it only reached significance in COUL-infected mice treated with nanocapsules $(p=0.009)$.

The determination of parasitic burdens showed a much lower variability among mice. In ME49-infected mice, both suspension and nanoparticle treatments resulted in a significant decrease of parasitic burdens (from 1.2 to $3.9 \log$ parasites $/ \mathrm{g}, p=0.009$ and 0.036 respectively), whereas in COUL-infected mice this decrease was only significant in those treated with nanocapsules (decrease of $1.2 \log$ parasite/g, $p=0.016$ ).

As a whole, these results showed that the activity of atovaquone is improved when used in nanoparticular form. Treatment with nanocapsules reduced significantly the parasitic burden ( $p=0.009$ for both strains), but not the cyst count, when compared to treatment with the suspension.

\section{DISCUSSION}

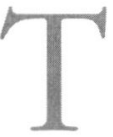

hese results confirm previous studies showing that atovaquone is an effective drug against T. gondii both in vitro and in vivo (Araujo et al., 1992; Romand et al., 1993). In the present study, we focused on the development of a new formulation of atovaquone in an attempt to obtain higher concentrations of drug in infected tissue, mainly in the brain, and to improve efficacy on the resistant cystic form of the parasite. Our choice was orientated toward nanocapsules which have a higher drug-loading capacity, are stable during storage, and can be given orally. Atovaquone-loaded nanocapsules were prepared after solubilization of the drug in benzyl benzoate. The stability of the nanocapsules, as assessed by following drug content, size, $\mathrm{pH}$ and osmolarity, was found satisfactory. Experimental assessment of the activity of atovaquoneloaded nanoparticules was conducted both in vitro and in vivo, and compared to the suspension form. Both formulations were found highly inhibitory for T. gondii in vitro with comparable $50 \%$ inhibitory concentrations. In a murine model of acute toxoplasmosis, the treatment with atovaquone-loaded nanocapsules at a low dosage $(15 \mathrm{mg} / \mathrm{kg} /$ day) was found remarkably efficient, compared to the suspension administered at the same dosage, resulting in the survival of $75 \%$ of the treated mice with a negativation of parasitic burdens in blood and brain and a marked reduction of lung infection. In chronic toxoplasmosis, treatment with both formulations of atovaquone resulted in a decrease of brain parasitic loads of treated mice compared to untreated controls. We noticed that this decrease was better evidenced by titration of parasitic burden using a tissue culture method rather than microscopic counting of brain cysts. Since the first method better estimates parasite viability, we believe that the cysts that were observed by microscopy may have lost part of their infectiosity potential, possibly in relation to some efficacy of the drug on the parasite-containing cysts.

The pharmaceutical formulation proved to have an important incidence, as already observed in the model of acute infection: for the two strains of $T$. gondii used in this study, the decrease of parasitic loads was significantly more important with atovaquone-loaded nanocapsules than with the suspension. Although we could not determine the concentrations of atovaquone in blood and tissues of treated mice, we believe that the better results obtained with atovaquone-loaded nanocapsules are related to increased bioavailability due to the drug solubilization in the oily core of nanocapsules. Finally, we noticed important differences in the result of treatment according to the infecting strain. Atovaquone nanocapsules were found to be more effective against the ME49 strain inducing a 4 log reduction of brain parasitic burden of treated mice, compared to a reduction of $1.5 \mathrm{log}$ in the brain of COUL-infected mice. These results corroborate the observation by Ferguson et al. (1994) who showed by electron microscopy that brain cysts of the ME49 strain contain a mixture of non-differentiated parasites, some of them resembling tachyzoites on which atovaquone would be more effective. By contrast, the COUL strain infection is characterized by a chronic phase with absence of brain tachyzoites and remarkable stable bradyzoite parasite burdens (Derouin et al., 1991) resulting in lesser sensitivity to atovaquone.

Such difference in the sensitivity of strain to atovaquone could be of consequences in clinical practice and could partly explain the high variability of interindividual responses noticed in clinical studies (Katlama, 1996). This would also confirm the hypothesis of Tomavo et al. (1995) according to whom the sensitivity of the different strains of $T$. gondii to anti-parasitic drugs are mainly correlated to their metabolic characteristics.

\section{ACKNOWLEDGEMENTS}

his work was supported in part by a grant from
the Universite Paris 7 .
We thank the two reviewers of the manuscript. 


\section{REFERENCES}

Araujo F.G., Huskinson-Mark J., GutTeridge W.E. \& RemingTON J.S. In vitro and in vivo activities of the hydroxynaphthoquinone 556C80 against the cyst form of Toxoplasma gondii. Antimicrobial Agents and Chemotherapy, 1992, 36, 326-330.

Araujo F.G., Huskinson J. \& Remington J.S. Remarkable in vitro and in vivo activities of the hydroxynaphthoquinone 566C80 against tachyzoites and tissue cysts of Toxoplasma gondii. Antimicrobial agents and Chemotherapy, 1991, 35, 293-299.

De Angelis D., Long J.D., Kanics L.L. \& WoOley J.L. Highperformance liquid chromatographic assay for the measurement of atovaquone in plasma. Journal of Chromatography, 1994, 652, 211-219.

Derouin F. \& Chastang C. Enzyme immunoassay to assess effect of antimicrobial agents on Toxoplasma gondii in tissue culture. Antimicrobial Agents and Chemotherapy 1990, 25, 708-711.

Derouin F. \& Garin Y.J.F. Kinetics of Toxoplasma gondii in blood and tissues during acute and chronic infections. Experimental Parasitology, 1991, 73, 460-468.

Devissaguet J.P., Fessi H., Ammoury N. \& Barratt G.M. Colloidal drug delivery systems for gastrointestinal application. In: Barriers to Drug Targeting and Delivery. Concept in dosage form design, Jungunger H.E. (eds), Ellis Horwood publishers, Chichester, UK, 1992, 71-79.

Ferguson D.J.P., Huskinson-Mark J., Araujo F.G. \& RemingTON J.S. A morphological study of chronic cerebral toxoplasmosis in mice: comparison of four different strains of Toxoplasma gondii. Parasitology Research, 1994, 80, 493-501.

Fessi H., Puisieux F., Devissaguet J.P., Ammoury N. \& Benita S. Nanocapsules formation by interfacial deposition following solvent displacement. International Journal of Pharmaceutics, 1989, 55, R1-R4.

Fusai T., Boulard Y., Durand R., Paul M., Bories C., Rivollet D., Astier A., Houin R. \& Deniau M. Ultratstructural changes in parasites induced by nanoparticles-bound pentamidine in a Leishmania major/mouse model. Parasite, 1997, 2, 133-139.

Girard P.M., Katlama C. \& Saïd G. Manifestations neurologiques. In: SIDA 1994, Pialoux G., Saimot A.G, Doin éditeurs, 82-86.

Howe D.K., Sibley L.D. Toxoplasma gondii comprises three clonal lineages: correlation of parasite genotype with human disease. The Journal of Infectious Diseases, 1995, 172, 1561-6.

Howe D.K., Honoré S., Derouin F. \& Sibley L.D. Determination of genotypes of Toxoplasma gondii strains isolated from patients with toxoplasmosis. Journal of Clinical Microbiology, 1997, 35, 1411-1414.

Hugues W.T., Kennedy W., Shenep J.L., Flynn P.M., HetheringTIN S.V. \& Fullen V. Safety and pharmacokinetics of 566C80, a hydroxynaphthoquinone with anti-pneumocystis carnii activity: a phase I study in human immunodeficiency virus (HIV) infected men. Journal of Infectious Diseases, 1991, 163, 843-848.
Huskinson-Mark J., Araujo F.G. \& Remington J.S. Evaluation of the effect of drugs on the cyst form of Toxoplasma gondii. The Journal of Infectious Diseases, 1991, 164, 170177.

Katlama C. Diagnosis and treatment of toxoplasmosis of the CNS in patients with AIDS. CNS Drugs, 1996, 5, 331-343.

Kreuter J. Drug targeting with nanocapsules. European Journal of Drug Metabolism and Pharmacokinetics, 1994 , 19, 253-256.

Leport C., Ambroise-Thomas P., Bazin C., Chene C., Derouin F. \& Katlama C. Les facteurs de risque de survenue d'une toxoplasmose cérébrale chez les patients infectés par le VIH. La Presse Médicale, 1996, 25, 519-520.

Piketty C., Derouin F., Rouveix B. \& Pocidalo J.J. In vivo assessment of antimicrobial agents against Toxoplasma gondii by quantification of parasites in the blood, lungs and brain of infected mice. Antimicrobial agents and Chemotherapy, 1990, 34, 1467-1472.

Puisieux F., Barratt G., Courraze G., Couvreur P., Devissaguet J.P., Dubernet C., Fattal E., Fessi H. \& Vauthier C. Polymeric micro and nanocapsules as drug carriers. In: Polymeric materials for biomedical applications, Dumetriu S. \& Szycher M. (eds.), M. Dekker, New York, 1994, 749-787.

Richards F.O., Kovacs J.A. \& Luft B.J. Preventing toxoplasmic encephalitis in persons infected with immunodefeciency virus. Clinical of Infectious Diseases, 1995, 21 (suppl. 1), S49-59.

Romand S., Pudney M. \& Derouin F. In vitro and in vivo activities of the hydoxynaphthoquinone atovaquone alone or combined with pyrimethamine, sulfadiazine, clarithromycin, or minocycline against Toxoplasma gondii. Antimicrobial agents and Chemotherapy, 1993, 37, 2371-2378.

Tomavo S. \& BoOTHROYD J.C. Interconnection between organellar functions, development and drug resistance in the protozoan parasite, Toxoplasma gondii. International Journal for Parasitology, 1995, 25, 1293-1299.

USPHS/IDSA prevention of opportunistic infections working group. USPHS/IDSA guidelines for the prevention of opportunistic infections in persons infected with human immunodeficiency virus: disease-specific recommendations. Clinical Infectious Diseases, 1995, 21 (Suppl. 1), S3243 .

Reçu le 14 janvier 1998 Accepté le 29 avril 1998 